Results of Infusion of Prostaglandin $F_{2 a}$ in Pregnant Women At or Near Term

\begin{tabular}{|c|c|c|c|c|c|c|c|c|c|c|c|c|}
\hline \multirow{3}{*}{$\begin{array}{l}\text { Case } \\
\text { No. }\end{array}$} & \multirow{3}{*}{ Age } & \multirow{3}{*}{ Gravida } & \multirow{3}{*}{ Maturity } & \multirow{3}{*}{ Indication } & \multirow{3}{*}{$\begin{array}{c}\text { Infusion } \\
\text { Time in } \\
\text { Hours }\end{array}$} & \multicolumn{2}{|c|}{ Cervical Dilatation } & \multirow{3}{*}{$\begin{array}{l}\text { Infusion/ } \\
\text { Delivery } \\
\text { Time }\end{array}$} & \multicolumn{4}{|c|}{ Baby } \\
\hline & & & & & & \multirow{2}{*}{$\begin{array}{l}\text { At Start } \\
\text { of } \\
\text { Infusion }\end{array}$} & \multirow{2}{*}{$\begin{array}{c}\text { At Finish } \\
\text { of } \\
\text { Infusion }\end{array}$} & & \multicolumn{2}{|c|}{ Weight } & \multirow{2}{*}{ Result } & \multirow{2}{*}{$\begin{array}{l}\text { Apgar } \\
\text { Score }\end{array}$} \\
\hline & & & & & & & & & lb. oz. & g. & & \\
\hline $\begin{array}{l}1 \\
2\end{array}$ & $\begin{array}{l}22 \\
28\end{array}$ & $\begin{array}{l}4 \\
6\end{array}$ & $\begin{array}{l}36 \\
39\end{array}$ & $\begin{array}{l}\text { I.U.D. } \\
\text { Prolapse of cord }+\end{array}$ & $\begin{array}{l}6 \\
4\end{array}$ & $\begin{array}{l}\text { Closed } \\
2 \mathrm{~cm} \text {. }\end{array}$ & $\begin{array}{l}6 \mathrm{~cm} . \\
8 \mathrm{~cm} .\end{array}$ & $\begin{array}{c}10 \mathrm{hr} \\
6 \mathrm{hr} .\end{array}$ & $\begin{array}{l}510 \\
8\end{array}$ & $\begin{array}{l}2,550 \\
3,630\end{array}$ & $\begin{array}{l}\text { Stillbirth } \\
\text { Stillbirth }\end{array}$ & 二 \\
\hline $\begin{array}{l}3 \\
4 \\
5\end{array}$ & $\begin{array}{l}28 \\
34 \\
28\end{array}$ & $\begin{array}{r}7 \\
11 \\
9\end{array}$ & $\begin{array}{l}44 \\
43 \\
34\end{array}$ & $\begin{array}{l}\text { Post-maturity } \\
\text { Post-maturity } \\
\text { Premature rupture } \\
\text { of membranes }\end{array}$ & $\begin{array}{l}2 \frac{1}{5} \\
3 \frac{1}{2} \\
2\end{array}$ & $\begin{array}{l}2 \mathrm{~cm} \\
2 \mathrm{~cm} \\
3 \mathrm{~cm}\end{array}$ & $\begin{array}{l}6 \mathrm{~cm} . \\
8 \mathrm{~cm} . \\
8 \mathrm{~cm} .\end{array}$ & $\begin{array}{l}6 \mathrm{hr} .30 \mathrm{~min} . \\
4 \mathrm{hr} .55 \mathrm{~min} . \\
5 \mathrm{hr} .30 \mathrm{~min} .\end{array}$ & $\begin{array}{l}8 \\
7 \\
4 \\
4\end{array}$ & $\begin{array}{l}3,630 \\
3,175 \\
2,100\end{array}$ & $\begin{array}{l}\text { Alive } \\
\text { Alive } \\
\text { Alive }\end{array}$ & $\begin{array}{r}9 \\
10 \\
6\end{array}$ \\
\hline $\begin{array}{l}6 \\
7 \\
8\end{array}$ & $\begin{array}{l}16 \\
31 \\
26\end{array}$ & $\begin{array}{l}1 \\
6 \\
7\end{array}$ & $\begin{array}{l}44 \\
40 \\
43\end{array}$ & $\begin{array}{l}\text { Post-maturity } \\
\text { Uterine inertia } \\
\text { Post-maturity }\end{array}$ & $\begin{array}{l}3 \\
2 \frac{1}{2} \\
1\end{array}$ & $\begin{array}{l}\text { Closed } \\
3 \mathrm{~cm} . \\
2 \mathrm{~cm}\end{array}$ & $\begin{array}{l}5 \mathrm{~cm} . \\
8 \mathrm{~cm} . \\
8 \mathrm{~cm} .\end{array}$ & $\begin{array}{c}12 \mathrm{hr} .30 \mathrm{~min} . \\
2 \mathrm{hr} .40 \mathrm{~min} . \\
2 \mathrm{hr} .\end{array}$ & $\begin{array}{lr}8 & 10 \\
5 & 13 \\
6 & 8\end{array}$ & $\begin{array}{l}3,910 \\
2,635 \\
2,950\end{array}$ & $\begin{array}{l}\text { Alive } \\
\text { Alive } \\
\text { Alive }\end{array}$ & $\begin{array}{r}8 \\
10 \\
8\end{array}$ \\
\hline 9 & 21 & 2 & 44 & Post-maturity & $\left\{\begin{array}{l}5 \\
1\}\end{array}\right.$ & Closed & $3 \mathrm{~cm}$. & Stopp & d contrac & after 7 & Jurs & 9 \\
\hline 10 & 22 & 2 & 38 & $\begin{array}{l}\text { Premature rupture } \\
\text { of membranes }\end{array}$ & $3 \frac{1}{2}$ & $2 \mathrm{~cm}$. & $6 \mathrm{~cm}$. & $8 \mathrm{hr} .20 \mathrm{~min}$. & 86 & 3,800 & Alive & 10 \\
\hline
\end{tabular}

In all cases the rate of infusion did not exceed $0.05 \mu \mathrm{g} / \mathrm{kg} . / \mathrm{min}$. In Cases 3 and 10 the rate of infusion was reduced to $0.025 \mu \mathrm{g} . / \mathrm{kg} / . \mathrm{min}$. after $1 \frac{1}{4} \mathrm{hours}$ and $2 \frac{1}{4} \mathrm{hour}$ respectively. One patient (Case 7) was an Asian; the remaining nine were African Negroes.

glandin $\mathrm{F}_{2 \alpha}$ was continued until the patient was established in labour as judged by strong regular contractions every two to three minutes and by a cervical dilatation of $5-6 \mathrm{~cm}$.

This preliminary study is too limited for comparison of the results with those of the only other drug available for the induction of labour-namely, oxytocin. A much wider investigation now in progress should enable us to make such a comparison.

The successful induction of labour with prostaglandin $F_{2 a}$ and the appearance of this substance in the maternal blood during labour and in close relation to uterine contractions previously reported tend to suggest that it has a physiological function in the process of parturition.

We wish to thank Mr. Raman Khiroya for technical assistance. Our thanks are also due to the medical and nursing staff of the labour ward. The work was supported in part by Makerere
University College Council Research Grant No. 410, which is gratefully acknowledged.

Requests for reprints should be addressed to S. M. M. Karim.

\section{REFERENCES}

Bergström, S., Carlson, L. A., Ekelund, L.-G., and Orö, L. (1965). Acta physiol. scand., 64, 332 .

Bergström, S., Duner, H., Euler, U. S. von, Pernow, B., and Sjövall, J. (1959). Acta physiol scand., 45, 145.

Bygdeman, M. (1964). Acta physiol scand., 63, Suppl. No. 242.

Bygdeman, M. (1967). In Prostaglandins, edited by S. Bergström and B. Samuelsson, p. 71. New York.

Bygdeman, M., Kwon, S., and Wiqvist, N. (1967). In Prostaglandins, edited by S. Bergström and B. Samuelsson, p. 93. New York.

Carlson, L. A. (1967). In Prostaglandins, ed. S. Bergström and B. Samuelsson, p. 123. New York.

Karim, S. M. M. (1966). F. Obstet. Gynaec. Brit. Cwlth, 73, 903.

Karim, S. M. M. (1968). Brit. med. f., 4, 618.

Karim, S. M. M., and Devlin, Jean (1967). F. Obstet. Gynaec. Brit. Cwlth, 74, 230 .

Karim, S. M. M., Somers, K., and Hillier, K. (1968). Europ. F. Pharma-

col., accepted for publication.

\title{
Gonorrhoea and the Intrauterine Contraceptive Device
}

\author{
R. STATHAM,* M.B., CH.B.; R. S. MORTON,* M.B.E., F.R.C.P.ED.
}

Summary : Though pelvic infection in women fitted with an intrauterine device (I.U.C.D.) is reported to be rare, three cases, gonococcal in origin, are presented. These case histories suggest that the presence of an I.U.C.D. increases the severity of gonorrhoea, while removal of the device before antibiotic therapy is probably essential for proper management. The literature and our experience suggest that where pelvic infection and an I.U.C.D. coexist gonorrhoea should be considered a likely diagnosis.

\section{Introduction}

Gräfenberg's intrauterine contraceptive device lost favour in the 1920 s owing to associated pelvic infection, sometimes fatal. In the last six or seven years new thoughts and materials have brought fresh designs and the I.U.C.D. is again in frequent and increasing use. Its hazards-spontaneous expulsion, pain, bleeding, and particularly pelvic infection-are therefore a matter for investigation.

* Department of Venereology, Royal Hospital, Sheffield.
Lippes (1965), using his I.U.C.D. types A and D, cited infection rates of 0.4 and 0.7 per 100 woman-years respectively. He stated that the few pelvic infections which did occur cleared quickly whether the device was removed or not. A World Health Organization Scientific Group (1966) considered that endometrial curettings, before and after insertion, show little difference in bacterial or cellular content. Such post-insertion changes as did occur were usually slight, subclinical, and reversible. The problem of introducing vaginal or cervical organisms when taking specimens was overcome by Mishell et al. (1966). They showed that where an I.U.C.D. had been fitted for a month or more before hysterectomy, transmural samples from such excised uteri were always sterile.

It therefore seems that the modern I.U.C.D. is rarely associated with infection either as a concomitant feature or as a later complication. The following three cases are worthy of note.

\section{Case 1}

\section{Case Reports}

A married woman aged 21 was prompted to attend hospital by the finding of recently acquired gonorrhoea in her husband, who 
admitted extramarital exposure 18 days previously. The couple agreed that their last marital intercourse occurred 11 days before the wife's attendance. She had been wearing an I.U.C.D. for three weeks, and had had a vaginal discharge for four days. Clinically there was inflammation of the urethral orifice and a mucopurulent vaginal discharge only. The I.U.C.D. was in situ, Gram-stained smears from the urethra and endocervix showed intracellular and extracellular Gram-negative diplococci, subsequently confirmed by culture and sugar fermentation tests to be gonococci. A diagnosis of uncomplicated gonorrhoea was made at her finst visit, and routine treatment, 1.2 mega units of aqueous procaine penicillin in one injection daily on two consecutive days, was prescribed. After the first injection she failed to attend for 48 hours. For fear of further default the dosage of the second injection was doubled. When she returned to her first follow-up examination five days later she complained of low abdominal pain and discomfort on defaecation. She looked ill but her temperature and pulse rate were normal. There was tenderness in both iliac fossae, confirmed on bimanual examination. Pelvic tenderness was markedly increased on movement of the cervix. The right Fallopian tube was thickened, readily palpable, and tender. Urethral and endocervical smears and, later, cultures were reported as showing no gonococci. Haematological findings from the initial visit, now available, showed a white blood cell count (W.B.C.) of 20,000 per cu. mm. with $82 \%$ polymorphs ; the E.S.R. (Westergren) was $25 \mathrm{~mm}$. in one hour.

A diagnosis of salpingitis probably due to gonorrhoea was made. The E.S.R. on this day rose to $47 \mathrm{~mm}$. in one hour. Rest and aqueous procaine penicillin 1.2 mega units daily for five days was ordered and completed. Symptomatic recovery was complete within 72 hours. On the last day of the course the W.B.C. was 11,000 per cu. mm. and the E.S.R. $13 \mathrm{~mm}$. in one hour. Ten days later the patient had a heavy menstrual period with loss of two large clots. At an examination after a further five days the I.U.C.D. was found to have been expelled spontaneously. Follow-up clinical, bacteriological, and haematological investigations on four occasions gave normal findings.

\section{Case 2}

A woman aged 27 , mother of five variously fathered children, all in local authority care, had been legally separated for seven years. She attended the department at our request as her regular consort had acquired gonorrhoea after "extramarital" coitus seven days previously. She gave a history of regular intercourse with this man and no other, the last occasion being a week before her attendance. She had been fitted with an I.U.C.D. a year previously.

Her complaint was of vaginal discharge for a week and low abdominal pain for three days, She looked ill, and her temperature was $99.8^{\circ}$ F. $\left(37.7^{\circ}\right.$ C.) and the pulse rate 88 per minute. She was tender suprapubically, and bimanual examination revealed such generalized pelvic tenderness that the Fallopian tubes could not be palpated. The patient was menstruating, and the I.U.C.D. was in situ. Smears were prepared from urethra, endocervix, and an infected Skene's gland, and stained with Gram's stain. All showed intracellular and extracellular Gram-negative diplococci, later confirmed by culture and sugar fermentation tests as gonococci, A diagnosis of gonococcal salpingitis was made. This received support from haematological investigations showing W.B.C. of 16,000 per cu. mm. with $90 \%$ polymorphs and an E.S.R. (Westergren) of $110 \mathrm{~mm}$. in one hour.

The patient was admitted to hospital and given a course of 1.2 mega units of aqueous procaine penicillin in one injection daily for five days. Within 24 hours the W.B.C. was 14,000 per cu. $\mathrm{mm}$. and the E.S.R. (Wintrobe) $54 \mathrm{~mm}$. in one hour. Clinical, bacteriological, and haematological progress was satisfactory and the patient was discharged.

She returned after 10 days with cervical gonorrhoea. This episode was believed at the time to be a reinfection rather than a relapse because a further risk of infection was admitted. The patient made an apparently satisfactory clinical and bacteriological response to routine treatment.

Nine months later she reattended complaining of severe suprapubic pain, worsening over the last week. She looked ill, and her temperature was $100.2^{\circ} \mathrm{F}$. $\left(37.9^{\circ} \mathrm{C}\right.$.) and pulse 108 per minute. There was marked suprapubic tenderness. Bimanual examination revealed thickening and tenderness in both lateral fornices, with pain extending into the abdomen and through to the lumbar region on movement of the cervix. The uterus was enlarged and tender, and the urine clear. The I.U.C.D. was in situ.

Gram-stained smears from urethra and endocervix showed a few Gram-negative diplococci in the cervical specimen only. Culture results subsequently obtained were reported as negative. A diagnosis of salpingitis with generalized pelvic infection, probably of gonococcal origin, was made. The haematological findings were W.B.C. 17,000 per cu. mm. with $84 \%$ polymorphs and E.S.R. (Westergren) $92 \mathrm{~mm}$. in one hour. In view of the severe pain the I.U.C.D. was removed. Relief was instantaneous. The patient was admitted to hospital and a five-day course of soluble penicillin, 1 mega unit six-hourly with $0.5 \mathrm{~g}$. streptomycin hydrochloride twice daily, was ordered. Clinical, bacteriological, and haematological follow-up tests on two occasions after discharge were satisfactory.

\section{Case 3}

An unmarried woman aged 20 who has two illegitimate children was referred by her general practitioner. There was a well-established history of promiscuity and epilepsy. For these reasons she had been fitted with an I.U.C.D. five months previously. Her recent history was of intercourse with three consorts, one regularly, in the three weeks before her attendance. Her complaint was of vaginal discharge, burning micturition, and increasing low abdominal pain. Her temperature was $101^{\circ} \mathrm{F}$. $\left(38.3^{\circ} \mathrm{C}\right.$.), and she looked ill. There was marked tenderness of the lower abdomen. On bimanual examination this was so severe that the examination could not be completed. The urethral orifice was inflamed, and there was a cascade of seropurulent discharge from the cervical canal. The I.U.C.D. was in situ. Gram-stained smears from urethra and endocervix showed intracellular and extracellular Gram-negative diplococci, later confirmed as gonococci by culture and sugar-fermentation tests. The W.B.C. was 7,000 per cu. $\mathrm{mm}$ and the E.S.R. (Westergren) $19 \mathrm{~mm}$. in one hour, A diagnosis of gonococcal salpingitis was made and the patient was admitted to hospital. Aqueous procaine penicillin 1.2 mega units was given immediately, followed by soluble penicillin 500,000 units six-hourly for four days. The patient responded satisfactorily and was discharged. At a second follow-up examination in the outpatient department nine days after discharge intracellular and extracellular Gram-negative diplococci were found in the endocervical smear. Gonococci were later cultured from both urethra and endocervix. For the same reasons as those given in Case 2 this episode was regarded as a reinfection rather than a relapse.

Seven months later the patient returned to the department complaining of a thin blood-stained vaginal discharge. Her last period had been unusually prolonged. She gave a history of frequent intercourse with her regular consort and with another seven days before this attendance.

The patient appeared to be well though her temperature was $99.6^{\circ}$ F. $\left(37.6^{\circ}\right.$ C. $)$. There was no abdominal tenderness. Bimanual examination revealed irregular thickening of the Fallopian tubes, particularly the left. The tubes were not tender. Urethral and endocervical smears and cultures on three consecutive days showed no gonococci. On the third visit, 48 hours after the first attendance, the temperature was still raised at $99^{\circ} \mathrm{F}$. $\left(37.2^{\circ} \mathrm{C}\right.$.) and there was pelvic tenderness on movement of the cervix and tenderness of the Fallopian tubes. There was no leucocytosis and the E.S.R. was $7 \mathrm{~mm}$, in one hour. A diagnosis of subacute/chronic salpingitis was made. The patient was readmitted to hospital and prescribed soluble penicillin 500,000 units intramuscularly six-hourly and streptomycin hydrochloride $0.5 \mathrm{~g}$. twice daily, each for five days. She made a satisfactory response and left hospital. She was discharged from care after a further two months.

\section{Discussion}

Gisslén et al. (1961) reported the incidence of pelvic infection complicating gonorrhoea in the female as $10 \%$. The only recent report in the United Kingdom comes from a paper read earlier this year at the Medical Society for the study of Venereal Diseases by Dr. Pamela Wray (personal communication). She found that $26(5.6 \%)$ of 458 cases had their infection complicated by salpingitis.

Seven women with gonorrhoea and wearing an I.U.C.D. have been seen by us in the last 18 months. Three of these cases, 
as reported above, have had salpingitis and possibly endometritis. Though the numbers are small, the high proportion showing pelvic spread must invite attention.

Estimation of the incubation period of salpingitis in gonorrhoea is classically difficult. We consulted a wide variety of the literature and standard textbooks of the last half-century and found them uninformative on the subject. A questionary was sent to 100 venereologists seeking their views. Forty-three of the 57 replies gave definite opinions. These suggested an association between the onset of salpingitis and recent menstruation-that is, at a time when reflux of menstrual debris and blood into the Fallopian tube is common. The consensus of the venereologists, not surprisingly, puts the incubation of salpingitis in gonorrhoea at two to five weeks. In our three cases the incubation period thus appears to be shortenedconsiderably so in Cases 1 and 2 . Our experience suggests that the morbidity of gonorrhoea is increased by the presence of an I.U.C.D.

It is of interest to speculate on the mechanism of this process.

The World Health Organization report referred to points out that various endometrial changes may occur in response to the action of an I.U.C.D. as a foreign body. In some women an I.U.C.D. may provoke menorrhagia and metrorrhagia. Such disturbances may well encourage spread of gonococcal infection, the damaged cells and blood forming a nutrient transport medium. Further, the uterine endometrium is a relatively anaerobic structure, much of its energy exchange being served by anaerobic glycolysis (Cohen et al., 1964). Kar et al. (1965) found consistently raised oxygen utilization in the uteri of rhesus monkeys fitted with I.U.C.D.s. Such a situation in humans would tend to make the uterine cavity relatively more anaerobic, especially if associated with excessive mucus production, as is commonly found with the I.U.C.D. The viability and spread of a facultative anaerobe such as the gonococcus would thus be favoured.

In this connexion it is of interest to note that in our Case 1 the development of salpingitis took place while the patient was receiving penicillin. In Cases 2 and 3 there must be some margin of doubt whether the early reappearance of infection really was due to reinfection and not perhaps to a failure to eradicate the organism. The subsequent history of these two cases gives some support to this possibility.
In contrast to Lippes's view (1965) we would suggest that in the presence of a gonococcal infection, even if apparently uncomplicated, any I.U.C.D. found in situ should be removed before antibiotic therapy is begun. This is now our practice. This recommendation follows the sound surgical principle of removal of a foreign body to assist drainage, potentiate treatment, and prevent or minimize complications.

As is widely agreed, pelvic infection in women fitted with modern I.U.C.D.s is not common. Our experience suggests that where pelvic infection does occur in a woman fitted with an I.U.C.D. gonorrhoea should be a prime consideration. The presence or absence of the gonococcus should be established by smears and cultures. It should thus be possible to make a prompt diagnosis in acute cases. Subacute or chronic cases, as our short series demonstrates, may prove more difficult. Examination of the sex partner or partners can be helpful. Gonorrhoea can be diagnosed with certainty and speed only by bacteriological methods carried out in conjunction with a laboratory familiar with the fastidiousness of the organism. In our opinion the gonococcal complement fixation test is not a reliable diagnostic aid; neither are smears taken from the vagina.

In our increasingly permissive society the I.U.C.D. is being more and more prescribed as a preventive. We submit that the above considerations have broad social, medical, and gynaecological implications and should arouse proportionately wide concern.

We would like to thank colleagues for their co-operation.

Postal expenses concerned with the questionary were met by a donation from a patient.

\section{REFERENCES}

Cohen, S., Bitensky, L., Chayen, J., Cunningham, G. J., and Russell, J. K. (1964). Lancet, 2, 56.

Gisslén, H., Hellgren, L., and Starck, V. (1961). Bull. Wld Hlth Org., 24, 367 .

Kar, A. B., Chowdhury, S. R., Kamboj, V. P., Chandra, H., and Chowdhury, A. R. (1965). Int. F. Fert., 10, 321.

Lippes, J. (1965). Amer. ¥. Obstet. Gynec., 93, 1024.

Mishell, D. R., jun., Bell, J. H., Good, R. G., and Moyer, D. L. (1966). Amer. F. Obstet. Gynec., 96, 119 .

W.H.O. Scientific Group (1966). Wld Hlth Org. techn. Rep. Ser., No. 332 , p. 13.

\section{Medical Memoranda}

\section{Anomalous Appearance of Peritoneum}

Brit. med. F., 1968, 4, 625-626

A recent single case of a peritoneal anomaly may prove of interest and stimulate the report of similar cases, the like of which I have been unable to find in the medical literature.

\section{CASE Report}

A 31-year-old married woman, gravida-8, para-7 (of which only five were still alive), requested during pregnancy that she be sterilized after delivery. She was a Kenyan Asian domiciled in England for three years, whose only significant history was of myxoedema seven years previously for which she received a maintenance dose of thyroxine ( $0.1 \mathrm{mg}$. daily). She booked late at 30 weeks, and was found to be anaemic-haemoglobin $63 \%$. No abnormal haemoglobins were detected on electrophoresis, but the serum iron was low at $40 \mu \mathrm{g} . / 100 \mathrm{ml}$. Iron-dextran (Imferon) was given as a total-dose infusion, and despite an initial poor reticulocyte response the haemoglobin rose to $75 \%$ at 39 weeks. She was surgically induced at term +15 days for postmaturity, and 15 hours later spontaneously delivered a living female infant weighing $7 \mathrm{lb} .3 \mathrm{oz}$. $(3,260 \mathrm{~g}$ ) ) after being in labour for 10 hours and 40 minutes.

With the written consent of both husband and wife, on the fourth day of the puerperium, laparotomy was undertaken to perform sterilization by cornuectomy. The abdomen was opened through a lower median incision and a 3-in. $(7.5-\mathrm{cm}$.) layer of fat was incised to reveal the rectus sheath, which was also opened in the midline by a vertical incision. The peritoneum was picked up between Spencer Wells forceps in the usual manner, but on palpation to exclude the adherence of bowel the peritoneum was felt to be abnormally thick. The commonly found peritoneal transparency was absent. A provisional diagnosis of old tuberculous peritonitis was considered, and a site for incision of the peritoneum was chosen as close to the umbilical end of the incision as possible, for though the bladder had previously been emptied by catheter the possibility that this thickened structure might be bladder was not absolutely excluded. 